\title{
WILDFIRE-INDUCED FOREST COVER CHANGE IN THE BARGUZINSKY NATURE RESERVE
}

\section{O. Zheleznyy}

Lomonosov Moscow State University, 1 Leninskiye Gory, Moscow, 119234, Russia

E-mail: olegzhelezn@gmail.com

Abstract. Every summer, wildfires caused by human activity and extreme weather conditions are ravaging vast areas of Siberian boreal forests. Due to its links to ecosystem change and carbon balance, it is particularly important to research forest recovery after these events. This work attempts to integrate remotely sensed and fieldwork data in order to explore the variability of after-fire succession due to environmental factors and burn severity in the Barguzinsky reserve. Additionally, we assess the applicability of spectral indices as a means of the forest regrowth estimation. Three key areas impacted by numerous fires since 1961 were selected for surveying, and a broad Landsat 5-7 imagery analysis had been carried out prior to it. Change of summer values of NBR spectral index provided information about burn severity, while annual changes in summer and early spring (illustrative of evergreen conifers) NDVI - about the intensity and direction of after-fire forest cover change. The results show high heterogeneity in succession processes, which can be attributed to environmental conditions. Boggy plains are characterised by slow but successful recovery of the larch (deciduous) and Siberian pine (establishing late and growing slow) forest, which, however, is poorly noticeable on satellite imagery. Drier areas within the plains and hill-slopes show a different pattern: they are rapidly occupied by pioneer species such as birch and fireweed, which constitute a full 'recovery' of NDVI after as little as 5-7 years after the fire. Resulting mixed birch and Scots pine stands with Siberian pine saplings highlight a substantial difference between secondary and intact coniferous taiga. Mountain fire site has much slower rates of recovery, the mosaic of which is majorly influenced by relief and microclimate. Suggested by imagery analysis differences in after-fire death rates of different species have also been confirmed by the field data.

Keywords: after-fire forest succession, NDVI, Baikal region, remote sensing, wildfires, burn severity, boreal forest.

Acknowledgements. The author expresses sincere gratitude for the organisation of the field work to the staff of the Barguzinsky reserve, including in particular N. Luzhkova, A. Egorov (volunteer), Yu. Gorokhovsky, I. Kurkina, T. Ananina and A. Ananin, as well as the MSU associate professor T. Kharitonova for useful advice and supervision, and undergraduate students M. Kozyreva, A. Kurop and M. Shilyakina for their invaluable help and support during the process of data collection.

For citation: Zheleznyy O. Wildfire-induced forest cover change in the Barguzinsky nature reserve. Russian Journal of Ecosystem Ecology. 2019;4(4). Available from: https://doi.org/10.21685/2500-0578-2019-4-1

УДК 528.88:574.42

\section{ВЫЗВАННЫЕ ПРИРОДНЫМИ ПОЖАРАМИ ИЗМЕНЕНИЯ ЛЕСНОГО ПОКРОВА БАРГУЗИНСКОГО ЗАПОВЕАНИКА}

\section{О. М. Железный}

Московский государственный университет им. М. В. Ломоносова, Россия, 119234, г. Москва, ул. Ленинские Горы, 1 E-mail: olegzhelezn@gmail.com

Аннотация. От антропогенных и вызванных экстремальными погодными условиями пожаров в Сибири каждое лето страдают обширные участки тайги. Взаимосвязь послепожарной динамики лесного покрова с экосистемными изменениями и углеродным балансом обусловливает ценность ее исследования. В данной работе осуществляется интеграция дистанционных и полевых наблюдений с целью изучения особенностей сукцессии в Баргузинском заповеднике, связанных с ландшафтными условиями и степенью поражения леса пожаром. Помимо этого, рассматривается использование спектральных индексов как средства оценки лесовосстановления. Для полевых работ были выбраны три участка, пострадавшие от нескольких пожаров с 1961 г.; был проведен предварительный анализ спутниковых снимков Landsat 5-7. Для оценки степени поражения леса пожаром использовались изменения летних значений индекса NBR, а для определения интенсивности и направления послепожарных изменений лесного покрова - ежегодная динамика летних и ранневесенних (характеризующих вечнозеленые виды) значений NDVI. Результаты показывают высокую гетерогенность процесса сукцессии, связанную с условиями среды. Так, для заболоченных низменностей характерно мед- 
ленное, но успешное восстановление кедрово-лиственничных лесов, которое, однако, плохо индицируется по дистанционным данным из-за листопадности лиственницы и замедленности восстановления кедра. Лучше дренируемые участки равнины и склоны сопок представляют иную картину: они быстро занимаются пионерными видами, в том числе березой и иван-чаем, что приводит к «восстановлению» летних значений NDVI через лишь 5-7 лет после пожара. Формирующиеся березово-сосновые молодняки с небольшой долей кедра сильно отличны от первичных малонарушенных темнохвойных лесов. Для гари в отрогах Баргузинского хребта характерны замедленные темпы восстановления, а также высокая мозаичность в связи со сложностью рельефа и сменой микроклиматов. Различия в скорости гибели древостоя разных видов деревьев после пожара, выявленные при анализе снимков, были также подтверждены полевыми наблюдениями.

Ключевые слова: пирогенная сукцессия растительности, NDVI, Прибайкалье, дистанционное зондирование, лесные пожары, поражение леса пожаром, бореальные леса.

\section{Introduction}

More than five million hectares of forest is annually burned in Russia as a result of wildfires [1], leading to carbon emissions, loss of forest resources and ecosystem change [2, 3]. Intact oldgrowth forests are currently covering a major part of Siberia, as well as Baikal region in particular, and human- or drought-induced wildfires pose a substantial threat to these landscapes. It is particularly important, therefore, to assess the recovery of habitats and key ecosystems in biosphere reserves suffering from wildfires - such as the Barguzinsky Nature Reserve (zapovednik), one of the oldest in Russia, that suffered substantial forest cover loss due to a drought in 2015 [4].

There have been numerous studies focusing on post-fire forest regrowth in Eastern Siberia [5-8]. These studies note the rapid death of species with thin bark, i.e. Pinus sibirica (cedar, or Siberian pine), Abies sibirica (Siberian fir), Pinus pumila (Dwarf pine); survival of thick-bark species, i.e. Pinus sylvestris (Scots pine) and Larix sibirica (Siberian larch), after fires of low severity, dominance of birch and aspen, Chamaenerion angustifolium (fireweed) and bunch grasses during the early stages of succession. According to various studies based in Baikal region, there are different paths of after-fire succession even within forests with similar composition, depending on the environmental conditions such as wetness and microclimate. Most of these researches, however, take place to the south of Baikal $[6,8]$; on KhamarDaban range in particular $[5,7]$, while northern territories, including the Barguzinsky range, stay underrepresented due to their remoteness and lack of human settlement that might be endangered by fires.

Large-scale field studies require substantial financial inputs and cannot be carried out frequently, especially in remote areas. Due to that, following a major development of remote sensing in recent decades, satellite imagery is increasingly used for various land cover studies, including vegetation dynamics and plant succession. These data, however, reflect a specific range of spectral character- istics of land cover and does not always correspond with the measurements acquired in the field. An accurate assessment of remote sensing applicability is required for various regions and goals of research.

The Normalised Difference Vegetation Index (NDVI), together with other spectral indices, are one of the most popular tools of accessing forest damage, destruction and reclamation [9], but require integration with field data, i.e. structural ground cover parameters, since they show the cumulative change in vegetation, and are often saturated prior to the actual recovery of the ecosystem due to establishment of grasses [10].

The aim of this work is to identify the trajectories of forest cover change in the reserve using both ground-based observations and remote sensing, and to investigate applicability of the latter for assessing these changes over larger parts of the reserve.

\section{Data and methods}

\section{Study area}

The data were collected in July 2019 within three key areas of the reserve that were impacted by predominantly ground (creeping) fires. The first one (a small area in the southwest, Fig. 1) is occupying a coastal, built of limnic sediments lowland to the south of the Tarkulik river mouth. The lowland is, however, not uniform in terms of relief and contains numerous flat hills and an escarpment towards the modern shore. This area was burned in 1995, and partly damaged again during the fires of 2015. The reference description point reveals the composition of native forests on the area: these are moderately dense stands of Pinus sibirica, Larix czekanowskii, Abies sibirica with Ledum palustre and Vaccinium vitis-idaea in the field layer. It is important to note that the researched territories lie at the very intersection of Larix sibirica and Larix gmelinii (Dahurian larch) ranges, and larch trees in all of the surveyed areas belong to a hybrid species Larix czekanowskii [11]. 

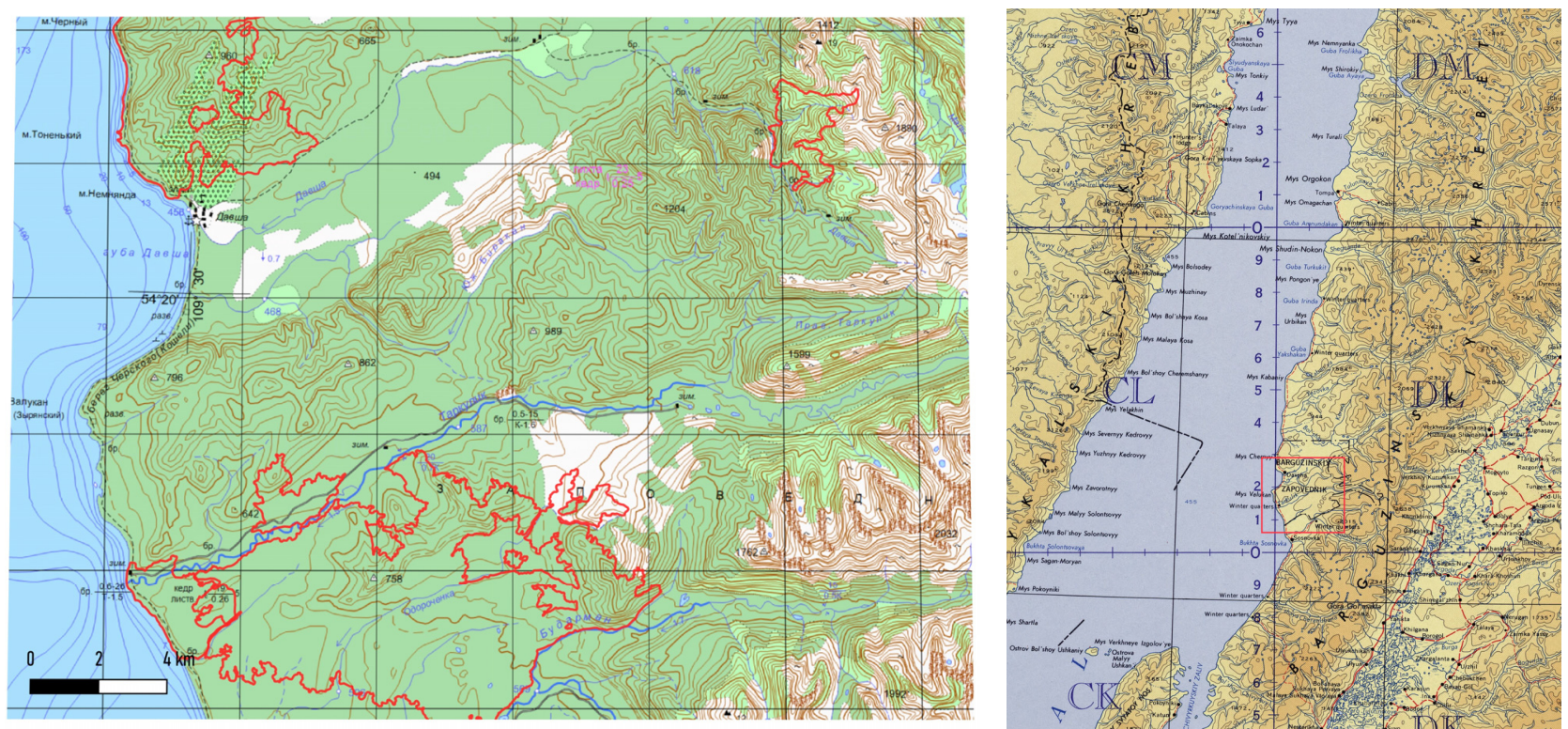

Fig. 1. Locations of the regions of study and surveyed burned areas (marked by red line in the left image)

The second area (in the northwest), to the north of the Davsha river and the research base of the reserve, mostly covers the slopes of relatively low (relative height 150-200 $\mathrm{m}$ above the lake level) hills, or sopki. According to the records [12], the 1961 fire that destroyed much of the native Siberian pine forest there, was human-induced. The vegetation had since recovered, but the fires of 2015 eradicated most of these young stands, creating a complex pattern of multi-age forest. The virgin forest, preserved in few unburned areas, is a complex community comprised of old (up to 290 years old) Pinus sibirica and Larix czekanowskii, abundant younger Abies sibirica, occasional Betula (a local hybrid of Betula platyphylla and pubescens), Gymnocarpium dryopteris and other boreal herbs (e.g. Linnaea borealis) in the field layer, green mosses. Forest in the lower part of the area is similar to the one found in the coastal lowland.

The third area (in the northeast), burned in 2006, is situated in the low mountains, at altitudes between 1200 and $1600 \mathrm{~m}$, in the upper reach of the Davsha river. It spans across a gradient of altitude zones, from Pinus sibirica and Abies sibirica forest with Pinus pumila in the undergrowth and 60-70 percent cover of green mosses to a Pinus pumila mountain scrubland with patches of bare rock and sand. A substantial amount of Pinus sylvestris is also present on drier and sunnier southern slopes. The field cover is scarce, with dominance of Vaccinium vitis-idaea.

\section{Methods}

The main objective of the field work was carrying out a geobotanical description [7] at the points located in diverse environmental conditions, yet impacted by a wildfire in the same year (Fig. 2). For each set of points, we took, where possible, reference points in unburned forests of different structure and composition. Square sample plots with side length of 10 meters were used for descriptions, that included, above the standard procedure, collection of dendrochronological records. Much attention was paid to accurate counting of tree saplings - one of the main indicators of forest recovery. Materials of the state forest survey implemented before the 2015 wildfire have also been used in planning the field work and analysing the results.

Beforehand, a database of atmospherically and radiometrically corrected Landsat 5, 7, 8 imagery was created, occupying a timespan of 30 years, since late 1980s until the present time. Each year is supplied by a summer (preferably late July, but early July and August for some years) and early spring (late March) NDVI image. The data were corrected by means of ESPA USGS system (summer imagery) [12], or DOS method in QGIS (early spring imagery that could not be corrected by ESPA method due to saturation attributed to the usage of the blue channel in the conditions of high reflectance of snowy slopes) [13]. All data underwent cloud and cloud shadow masking using Landsat QA band.

For the assessment of burn severity, we used dNBR (see Fig. 2), the difference between the summer Normalised Burn Ratio few days or weeks before (depending on the availability of quality imagery) and one year after the fire. So, dNBR is highly sensitive to changes in leaf wetness and chlorophyll content [14], and is categorised as follows: above 0.66 - high severity fire, between 0.66 and 0.27 - moderate severity, between 0.27 and 0.1 - low severity, below 0.1 - no damage [15]. 

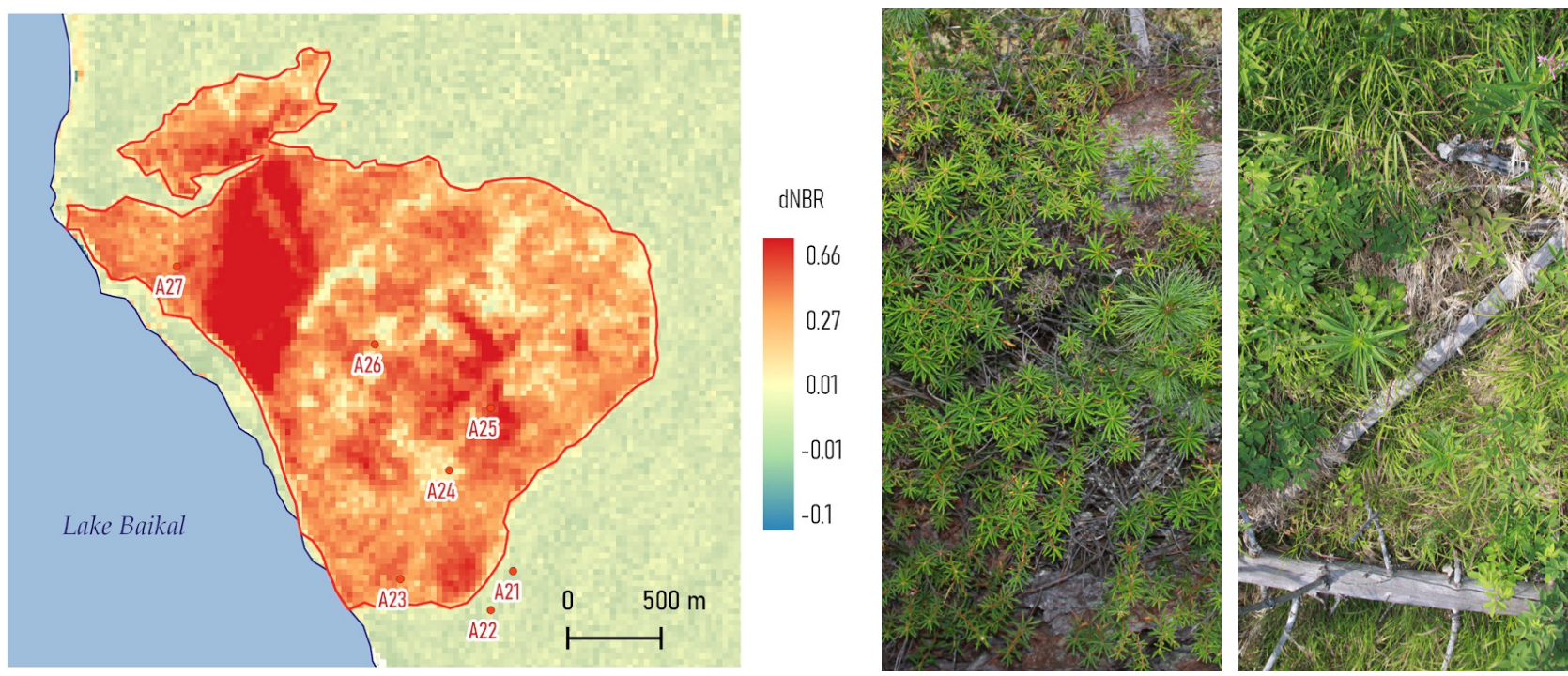

Fig. 2. Area burned in 1995: dNBR and examples of ground cover from points 23 (middle) and 25 (right).

Projection UTM WGS84 zone $49 \mathrm{~N}$ here and further

Additional to categories of fire severity, very small polygons with uniform forest patches were digitised around each field work point in order to study the annual dynamics of NDVI in selected burned or intact patches and assess its spatial variability. We used a Python code for calculating average NDVI, as well as descriptive statistics for each polygon or severity category.

\section{Results and discussion}

The first area, despite relative uniformity of initial forest cover and environmental conditions, presents a highly differentiated picture of regrowth (Fig. 3). Change in summer NDVI following afterfire regrowth is generally inversely proportional to burn severity, as a comparison of Fig. 2 and 3 can suggest. Indeed, the field layer and deciduous trees have recovered throughout the whole area. But un- seen by the index, there is a major difference between lower and higher parts of the burned area. The flat plain, seasonally waterlogged, has slower rates of recovery, exemplified by points 23 and 27 (Fig. 4). Meanwhile, the points located on a hill (relative height about $40 \mathrm{~m}$ ), even those with high burn severity (point 25), return to pre-fire NDVI levels in 6-7 years. The field descriptions show the reason for such major difference: in low areas, a native, similar to the intact ones, community is recovering: congestions of young Larix czekanowskii around old, undamaged by fire trees with bark thickness 10-15 cm; recently established Pinus sibirica saplings; Ledum palustre, various Vaccini$u m$ shrubs and green mosses. The better drained, higher area of the hill is characterised by intensive establishment and growth of Betula, Duschekia fruticosa, Chamaenerion angustifolium, Calamagrostis langsdorfii, Rubus arcticus (in patches).
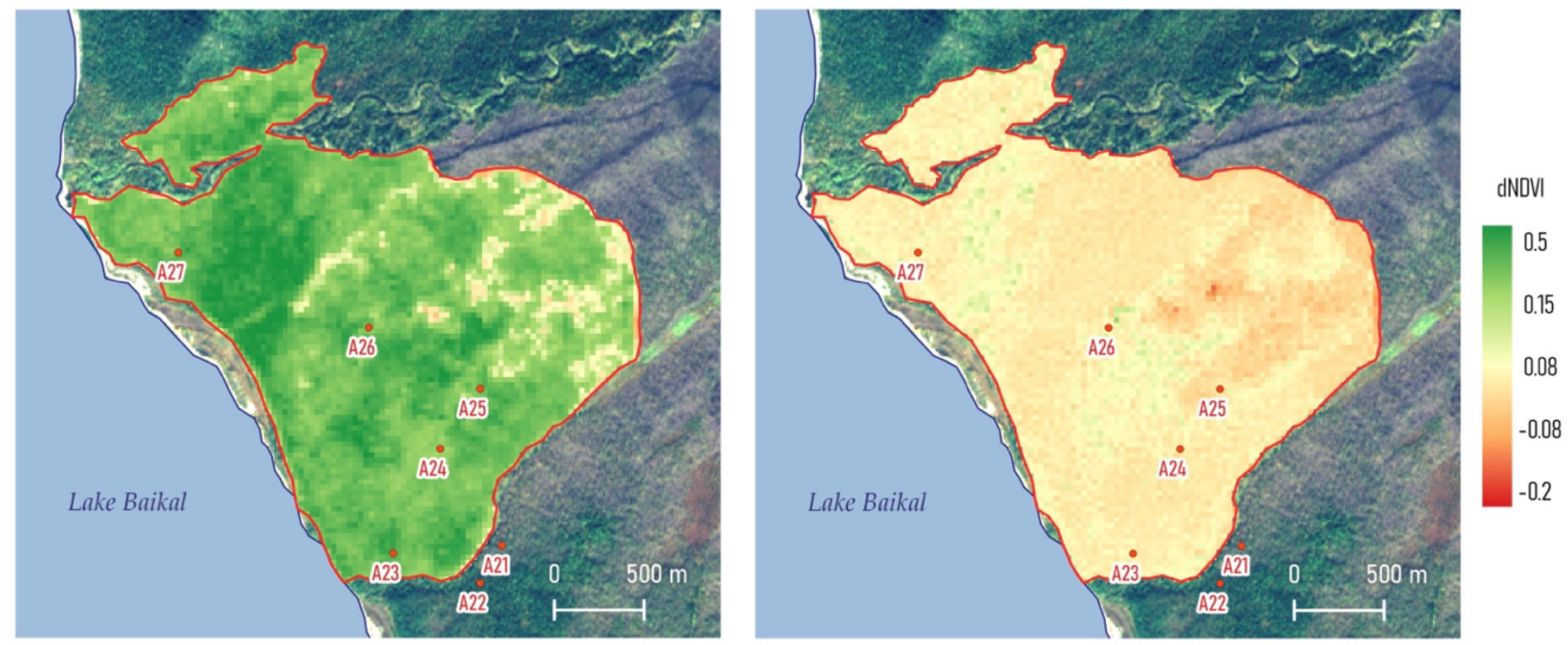

Fig. 3. Area burned in 1995: left - changes in mid-summer NDVI in 1996-2019, right - changes in early spring NDVI in 2000-2019 


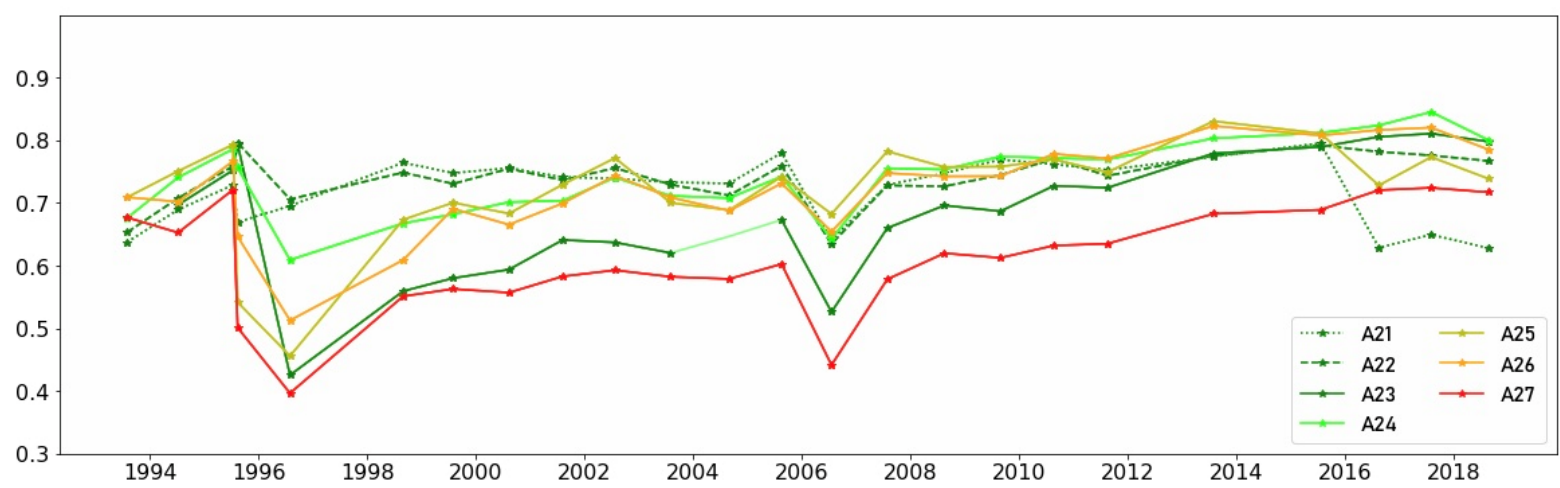

Fig. 4. Area burned in 1995: dynamics of summer NDVI (y axis) for surveyed points in 1993-2019

The prolonged death of evergreen conifers (Abies sibirica and Pinus sibirica) is evident from the imagery: early spring NDVI (Fig. 5) had been decreasing for 3-4 years following the fire, and then staying at a low level for more than ten years, later increase in early spring NDVI is minor, but clearly noticeable around the intact forest edge, in the areas with high burn severity, and in the betterdrained relatively high areas, e.g. point 26 on the hill slope, where patches of Abies sibirica have successfully established around 20 years ago (as seen from tree cores) and now reach heights of 7-8 $\mathrm{m}$. The reasons for such a distribution are likely to be both the way of seed dispersal - the cones are spread by Spotted nutcracker (Nucifraga caryocatactes) and Siberian chipmunk (Eutamias sibiricus), - and environmental conditions: better soil drainage and mineralisation of the substrate after the fire. The amount of new saplings in these areas, however, is smaller than in the low ones, mostly because of relatively high covers of herbs and shade from young birches or conifers (Fig. 6).

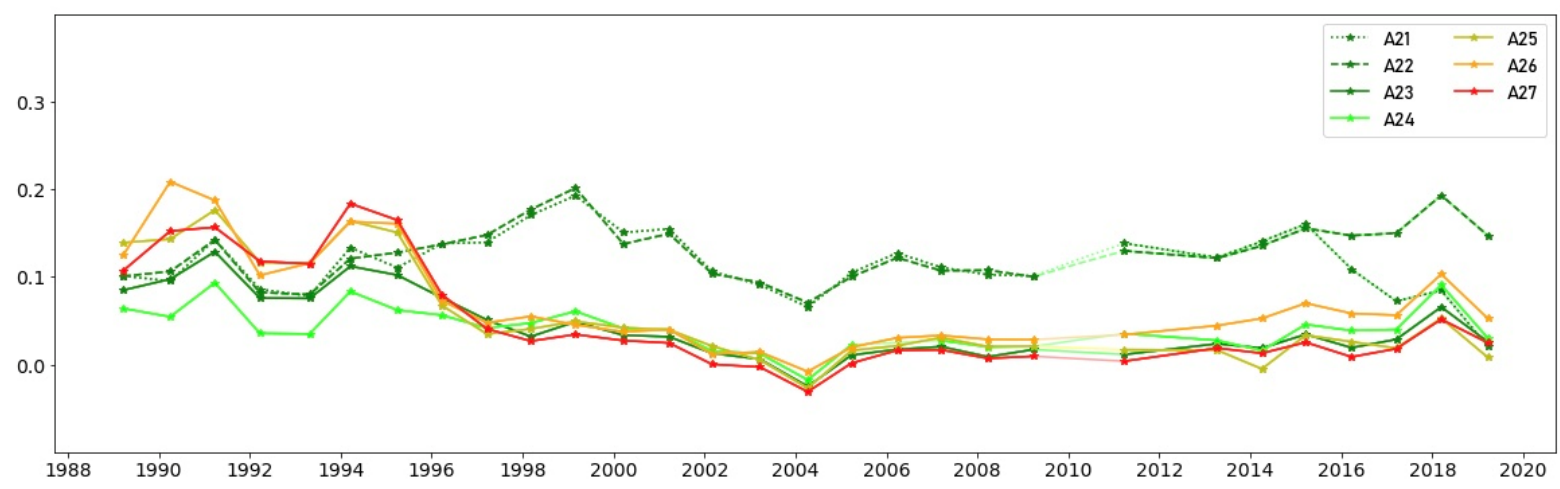

Fig. 5. Area burned in 1995: dynamics of winter NDVI (here and further y axis) for surveyed points in 1989-2019

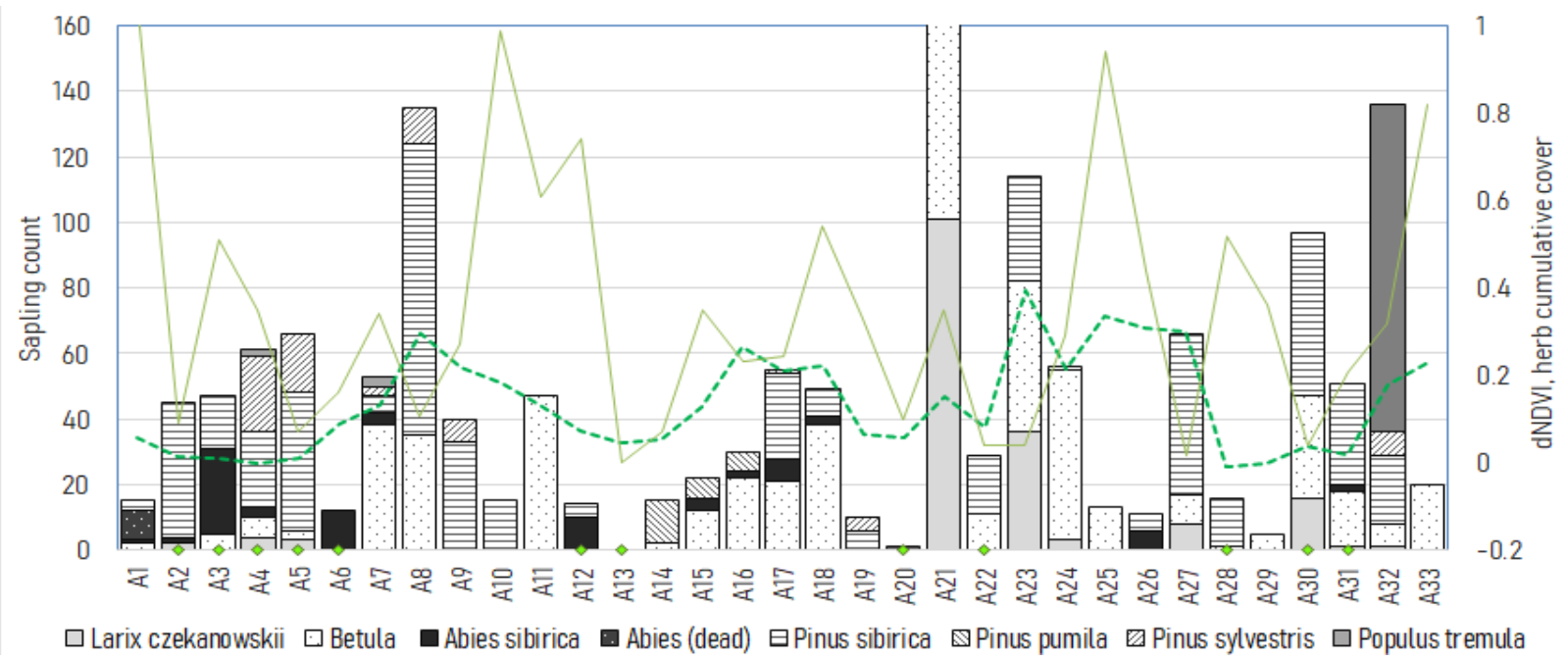

Fig. 6. Numbers of shoots and saplings of different species; the difference in July NDVI between the year of the latest fire (different for every point) and 2019 (dNDVI, dashed line), and cumulative cover of herbaceous vegetation (not including any shrubs or mosses, hard line). Diamonds identify patches not impacted by fire. Column of birch saplings at A21 exceeds the frame and reaches as far as 751 
This area is also the western frontier of a massive fire site of 2015 (see Fig. 1). Two of the surveyed points $(21,25)$ are within the burned area, and they present a different picture: the one that was already burned in 2015, had been since covered with dense herbs and groups of birch trees, and quickly recovered after the fire of low severity, which in the absence of old larch trees around allowed only for a small amount of birch saplings (see Fig. 6). The other one, a patch of intact forest, has a mosaic of burnt, occupied by rare Chamaenerion angustifolium and unburned Ledum palustre peat hummocks. This area has the highest recorded amount of Betula and Larix saplings (650 and $100)$, most of which are still too small $(8-12 \mathrm{~cm})$ to drive a substantial increase in NDVI, but it can be expected in the following years. This abundance of saplings is, apparently, related to the formation of mineralised clearings and survival of most of the Larix trees. There has only been one Pinus sibirica sapling recorded, for nearly all of the adult trees of these species have died, as seen from spring NDVI (see Fig. 5).
A major challenge of using satellite imagery for assessing taiga regeneration is the omission of Lar$i x$ in early spring NDVI. Therefore, patches of recovering coniferous forest cannot be always separated from deciduous secondary groves. A more advanced method, e.g. application of autumn imagery shall be used for a fuller assessment of forest recovery.

We only surveyed the southern part of the vast burned area to the north of Davsha (Fig. 7). Although the summer NDVI values of the area burned in 1961 had already been long recovered in 2015, the early spring index could not reach the level of that of the intact forest, even though the latter included substantial amounts of larch. The share of evergreen vegetation, however, was increasing, as can be seen as a reason for shortening of early spring NDVI standard errors in the 2000s (Fig. 8). The recovery of conifers had been most successful on less favourable for early-successional species northern and western slopes, in steeper and better drained areas (see Fig. 7).
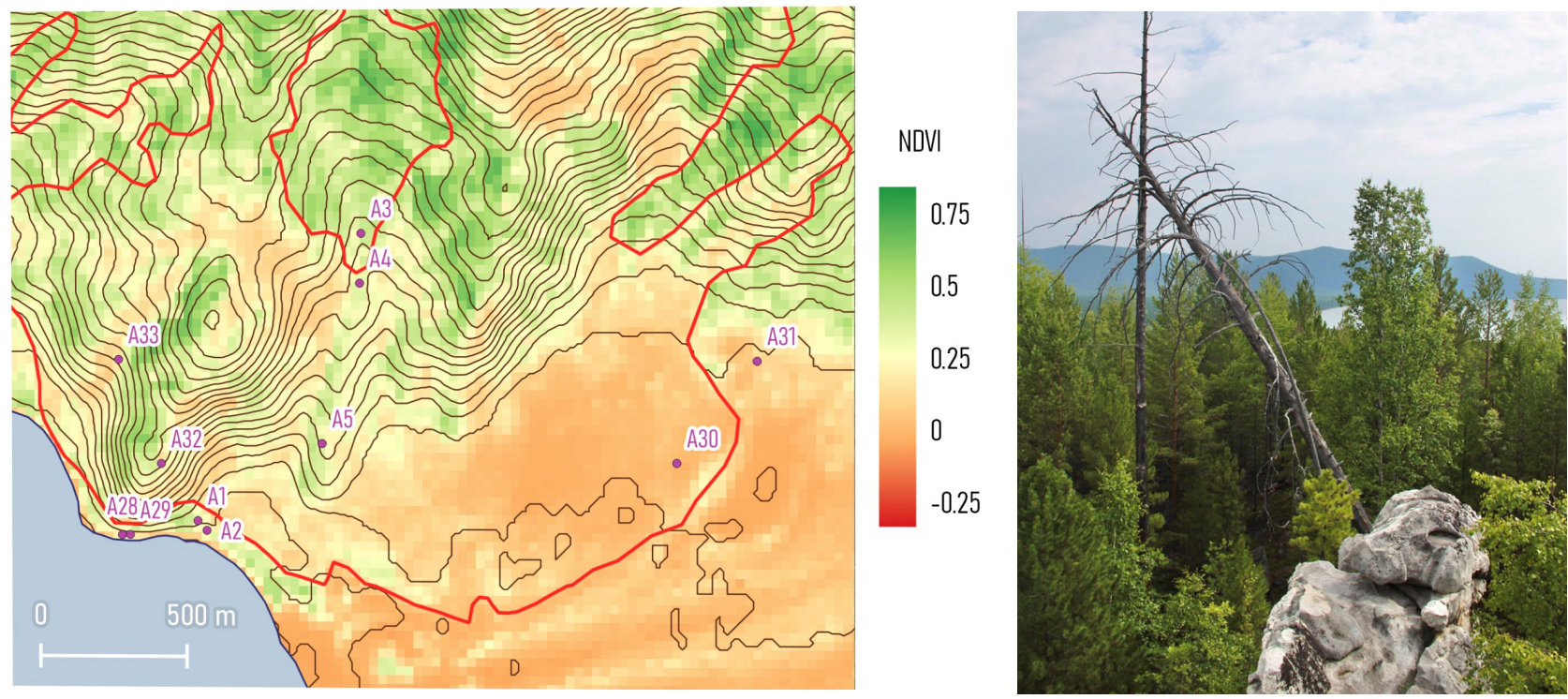

Fig. 7. Left: area burned in 1961 (outlined) and later in 2015. March 2015 NDVI. Right: an example of after-1961-fire vegetation: Pinus sylvestris and Betula forest, dead Larix and Pinus sibirica. North of point 5

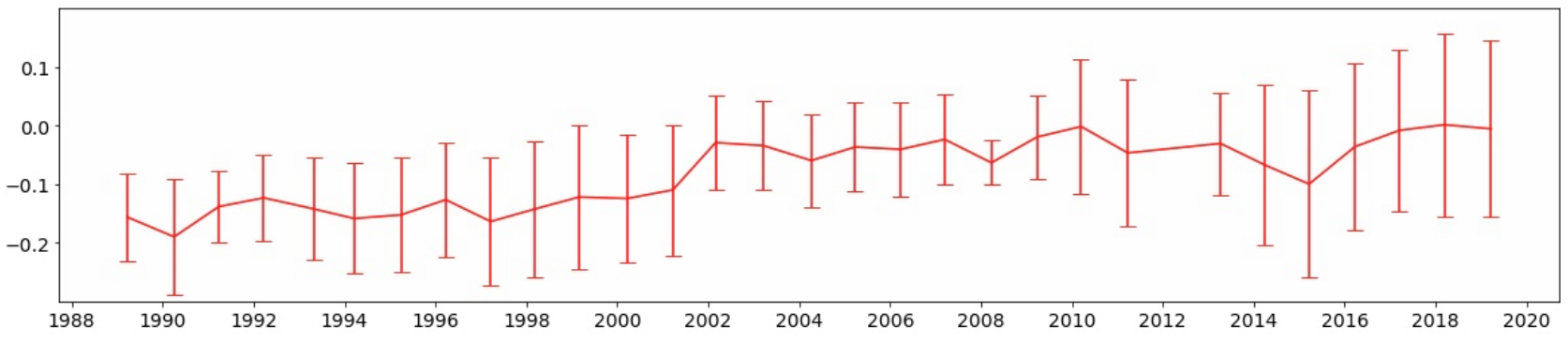

Fig. 8. Differences between average NDVI within the area burned in 1961 and the unburned buffer zone

However, preserved after-fire stands show a very different structure from the forest in the reference plots. Two main types of after-fire vegetation can be noted here: the first - Pinus sylvestris and Larix czekanowskii forest with share of Betula and relatively sparse field layer comprised of Bergenia 
crassifolia, Calamagrostis langsdorfii, Linnaea borealis in wetter areas, and Vaccinium vitus-idaea in drier areas (points 4,5). Regrown forest of the second kind, unfortunately, was mostly burned in 2015, but as seen from remaining trees and Forest Survey data, there was a mosaic of Pinus sylvestris mixed with Populus tremula patches, dense Betula groves and younger congestions of Pinus sibirica, reaching $12-15 \mathrm{~m}$ in height. The amount of Larix is substantially smaller than in wet areas, partly because many of the old trees had already had low vitality which was further decreased by the fire. Hollows affected by the fire of medium and high severity (suggested by absence of any old trees there) have been covered with Betula woodlands with Rosa acicularis and dense grasses. The low area that was burned in 1961 has a similar to 1995 area pattern of recovery, at least within the mires (points 30-31), but is also characterised by considerable amounts of Pinus sylvestris and boreal herbaceous cover in better drained parts.

There is a substantial variability between areas with different environmental conditions, but the replacement of Abies sibirica and Pinus sibirica with faster growing and more fire-tolerant Pinus sylvestris can be considered as the general trend.

The area has still not recovered from the 2015 fire, and the summer NDVI has only returned to previous values where the fire impact was not severe. Wetter, concave slopes are now overgrown with Chamaenerion angustifolium, Calamagrostis langsdorfii, Deschampsia turczaninowii and Rubus matsumuranus, while better drained have rare plant cover, although greater numbers of tree saplings. Some of the damaged deciduous trees, however, show intensive vegetative regeneration, producing dense thickets of young trees (e.g. point 32).

The amount of saplings in the intact forest patches is generally above 40 per plot, and quite diverse; it always includes Pinus sibirica, and often Abies sibirica. Burned areas have fluctuating numbers of saplings, since the recovery is very uneven, and are lacking the species mentioned above. The main reason is likely to be the habitat loss: birds and chipmunks are more likely to store cones in unburned forests with intact floor litter and moss cover. Even the first to establish after the 1961 fire Pinus sibirica trees had not reached the age of successful cone production, and therefore could not enrich the soil seed budget, unlike in those cases where the forest was only burned once. Most of the 40-50-year old trees here died, but have not yet fallen onto the ground.

The mountain fire site presents a rare for the region of study example of after-fire vegetation dynamics in mountain forests. As noted in the introduction, the site spans across a number of altitude zones, slopes of different aspect and steepness. The wetter valleys were generally intact after the fire, including minor ones, which brought about high diversity of land cover and conifers' refugia that can serve as animal habitats and sources for seed dispersal (Fig. 9). Throughout the whole year, NDVI values of the burnt area are still low, especially on convex steep slopes. Early spring NDVI shows a difference in fire-induced death rates of wet valley and drier slope forests: for Pinus sibiri$c a$ and Abies sibirica forest, the values plunge in two years following the disturbance, while for $P i$ nus sylvestris and Pinus sibirica forest they require about 8 years to reach the minimum (Fig. 10). Generally, the former diversity of spring NDVI had been levelled down to zero in years following the fire. However, thanks to the availability of seed sources, recovery of evergreen conifers can be seen from the index, yet only in the recent years, partly due to the snow cover, partly due to severe climate conditions that serve as a major limiting regrowth factor. There also is an issue with indicating the recovery of Pinus pumila shrubland (points 13-14) due to the low quality of spring imagery of rugged, covered with snow terrains. There are major fluctuations of the index depending on the sun elevation and distribution of shadows; there can be an increased reflection, and southern slopes, that provide the main habitat for these species show saturation of channels in visible spectrum. However, the field survey revealed that the levels of Pinus pumila recovery, as noted in the previous studies [5] and supported by summer NDVI (Fig. 11), are very low, and the burned terrain is occupied by a very rare cover of herbs, including Chamaenerion angustifolium, Aconogonon ajanense and Vaccinium vitis-idaea.

Recovering summer NDVI has lower values than in the lowlands at the same time after the fire; it is also very uneven (see Fig. 11). Except for the valley bottoms that suffered fire of lower severity and have more favourable conditions in general, the density of herbaceous vegetation is low as a result of lack of water and decreased influence of the lake meaning severe winter conditions. Because of that, however, the site presents a clear relationship between sapling count and NDVI change (see Fig. 6): the site is dominated by 1-5 $\mathrm{m}$ high Betula (40-50 per plot), $0.5 \mathrm{~m}$ Pinus sylvestris, and $0.2-0.3 \mathrm{~m}$ Pinus sibirica. Absence of Betula saplings on southern slopes is probably the effect of seasonal dryness. The amount of saplings has a negative relationship with altitude and is greater on northern slopes (points 8,11 ) and in wetter areas by the streams (pounts 7,11,18). It can be seen in comparison of points 8 and 9: the former, located on the northern slope, was damaged more severely than the latter, but had evened and exceeded its NDVI recovery levels. Points 7 and 11 had similar burn severity and slope aspect, yet the latter has much faster recovery rates due to a lower slope steepness. Points 
7 and 19 showed fast summer NDVI recovery rates, but 6 years after the fire the index started decreasing again, which might be related to the disruption of ecosystem balance: decrease of soil wetness following the death of conifers that caused microclimate change and low resilience to summer droughts due to a rare canopy cover. Wetter areas also have a more diverse herbaceous vegetation, including patches of Carex globularis, abundant Vaccinium myrtillus, Vaccinium vitis-idaea, Linnaea borealis, green mosses.
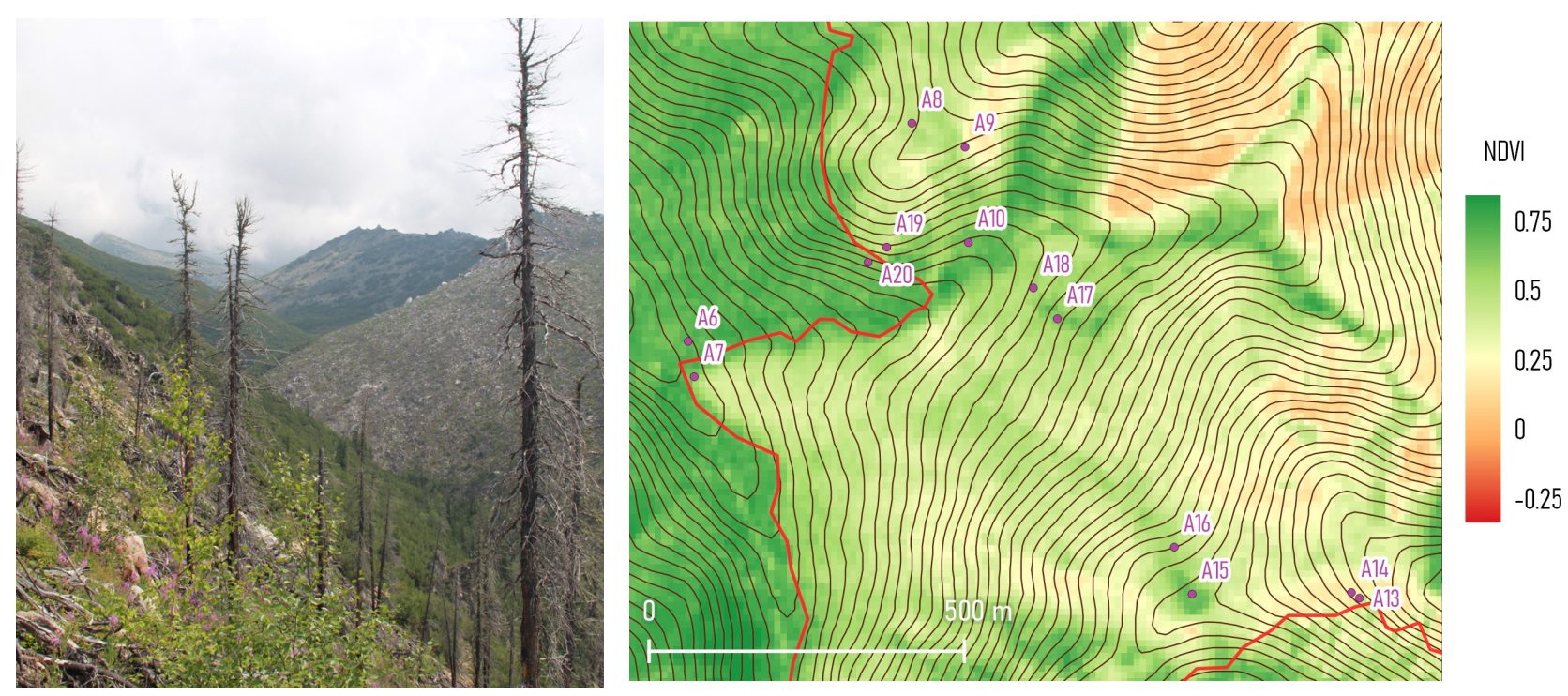

Fig. 9. Area burned in 2006 (outlined): general view (towards point 13); surveyed points over July 2019 NDVI
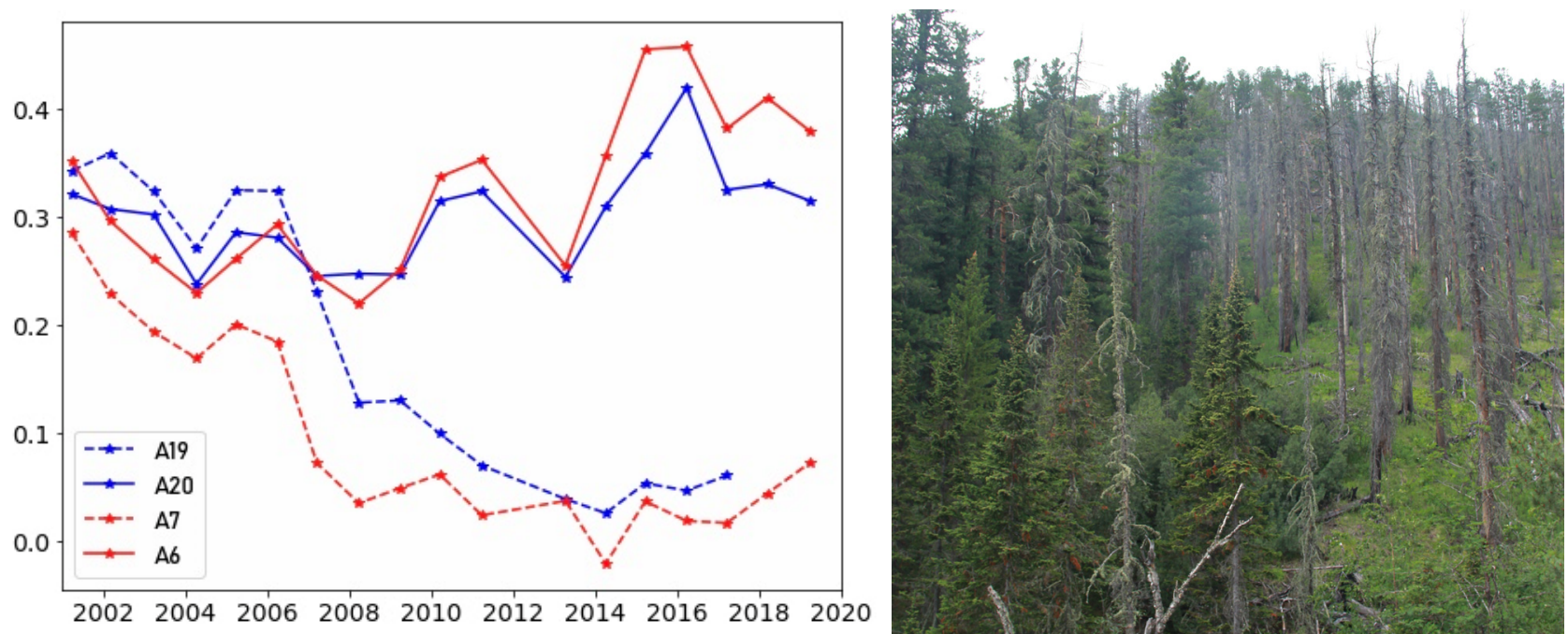

Fig. 10. Area burned in 2006: left - early spring NDVI dynamics; right - fire severity gradient: Abies sibirica in the lower part of the slope, survived Pinus sylvestris in the upper

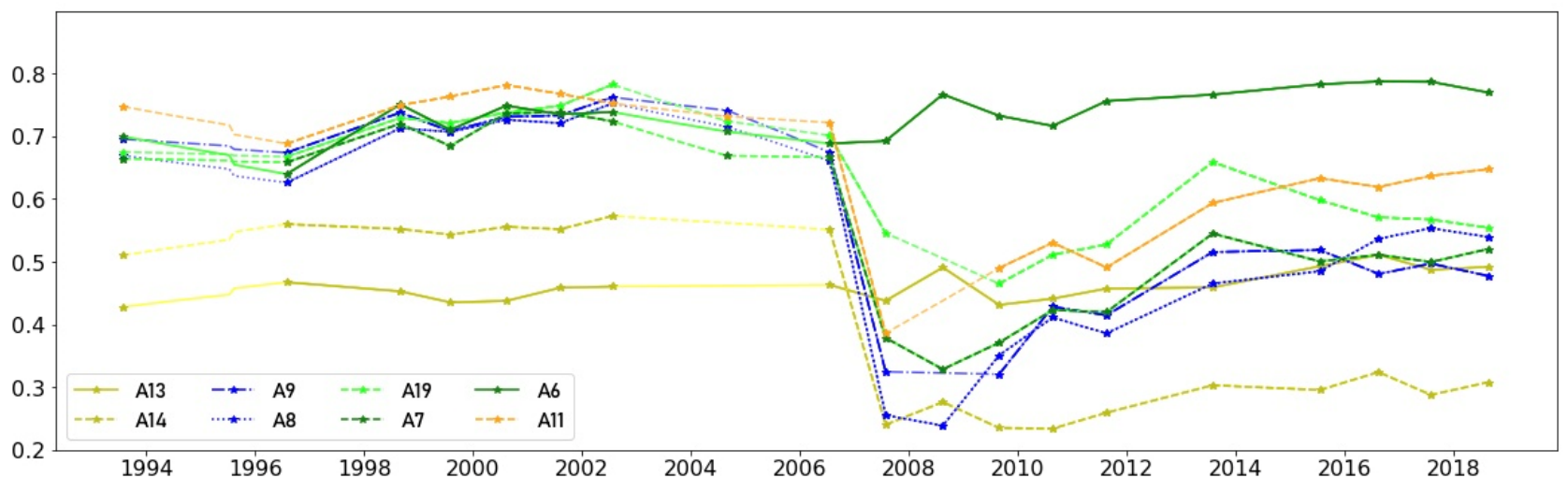

Fig. 11. Area burned in 2006: summer NDVI dynamics for the selected points 
The relationship between NDVI and groundmeasured data is complex and requires processing and inclusion of additional data such as Leaf Area Index, moss and shrub cover, etc. However, even a rough analysis of Fig. 6 shows that links between changes in summer NDVI and sapling count exist and are more pronounced than those with herbaceous vegetation cover, which, however, does influence some of the areas, especially in early years of recovery. One of the reasons for that can be the fast establishment of pioneering grasses and herbs in the year following the fire. The relationship weakens as saplings grow denser creating a negative feedback and decreasing the number of shoots.

The results confirm a number of previous findings concerning after-fire succession $[4,6,16,17]$. The specific features of the studied areas include the important role of Pinus sylvestris in young stands, as well as the slow pace of native forest recovery, and the successful recovery of Larix czekanowskii forests, including the field layer. A more generic, based on multi-band satellite imagery approach is required for further mapping and classification of after-fire ecosystem recovery across larger territories.

\section{Conclusions}

Although the territory is diverse, and the survey coverage is small, we tried to encompass ecosystems with diverse landscape conditions, forest structure and fire history. Therefore, the following paths of after-fire recovery can be proposed for different types of forest:

a) Larix czekanowskii, Pinus sibirica and Abies sibirica lowland forest with Ledum palustre and various Vaccinium recovering with a similar composition of species, yet increased amounts of Larix; b) Pinus sibirica forest with Larix, Betula, Abies sibirica, Pinus sylvestris, Vaccinium vitisidaea, boreal herbs and green mosses recovering as Betula and Pinus sibirica woodland with patches and hummocks of grasses, Vaccinium vitis-idaea, Chamaenerion angustifolium;

c) Pinus sylvestris, Pinus sibirica and Larix forest with Vaccinium vitis-idaea recovering as a Pinus sylvestris and Betula forest with similar ground cover;

d) Pinus sibirica mountain woodland with dense Pinus pumila and occasional Abies recovering as a Betula woodland with Pinus sibirica, Vaccinium shrubs and grasses;

e) Pinus sylvestris and Pinus sibirica mountain forest with Pinus pumila recovering as a Pinus sylvestris woodland with grasses.

After-fire death and regrowth of evergreen conifers is well-indicated by the dynamics of early spring NDVI, even in case of minor changes and mosaic forest structure. Summer NDVI shows the rate of vegetation recovery, including variability related to wetness and altitude, yet cannot directly attribute for the qualitative changes. While low, boggy plains preserve the native composition of species (the Larix czekanowskii and Pinus sibirica forest), better drained hill-slopes are characterised by the intervention of early-successional species (Betula, Pinus sylvestris). The latter leads to a rapid saturation of summer NDVI values, but in combination with exhausted soil seed bank leaves little opportunity for the recovery of conifers. Change in NDVI shows a connection with the amount of new saplings and shoots, but only within a particular time frame after the fire which itself depends on the environmental factors, such as microclimate, soil wetness and herbaceous vegetation cover.

\section{References}

1. Спутниковый мониторинг лесных пожаров в 21 веке на территории Российской Федерации (цифры и факты по данным детектирования активного горения) / Е. А. Лупян, С. А. Барталев, И. В. Балашов, В. А. Егоров, Д. В. Ершов, Д. А. Кобец, К. С. Сенько, Ф. В. Стыценко, И. Г. Сычугов // Современные проблемы дистанционного зондирования Земли из космоса. - 2017. - № 14 (6). - С. 158-175.

2. Цветков, П. А. Исследование природы пожаров в лесах Сибири / П. А. Цветков, Л. В. Буряк // Сибирский лесной журнал. - 2014. - № 3. - С. 25-42.

3. Determining effects of area burned and fire severity on carbon cycling and emissions in Siberia / S. G. Conard, A. I. Sukhinin, B. J. Stocks, D. R. Cahoon, E. P. Davidenko, G. A. Ivanova // Climate Change. - 2002 . - № 55. P. 197-211.

4. Изучение естественного хода процессов, протекающих в природе, и выявление взаимосвязей между отдельными частями природного комплекса на территории Баргузинского государственного природного биосферного заповедника им. К. П. Забелина. Летопись природы 2015 г. / под ред. А. А. Ананина, Т. Л. Ананиной. - Усть-Баргузин : Заповедное Подлеморье, 2016. - 220 с.

5. Гамова, Н. С. Пирогенные смены лесной растительности центральной части Хамар-Дабана (Южное Прибайкалье) / Н. С. Гамова // Проблемы ботаники Южной Сибири и Монголии : сб. науч. ст. по материалам XIII Междунар. науч.-практ. конф. - Барнаул : Концепт, 2014. - С. 55-59. 
6. Краснощеков, Ю. Н. Постпирогенная дигрессия лесных экосистем в горном Прибайкалье / Ю. Н. Краснощеков, М. Д. Евдокименко, А. А. Онучин // Сибирский лесной журнал. - 2018. - № 6. - С. 46-57.

7. Краснощеков, Ю. Н. Лесоэкологические последствия пожаров в кедровниках Южного Прибайкалья / Ю. Н. Краснощеков, М. Д. Евдокименко, Ю. С. Чередникова // География и природные ресурсы. - 2013. № $1 .-$ C. 33-42.

8. Краснощеков, Ю. Н. Послепожарное функционирование лесных экосистем в Восточном Прибайкалье / Ю. Н. Краснощеков, М. Д. Евдокименко, Ю. С. Чередникова, М. В. Болонева // Сибирский экологический журнал. - 2010. - № 17 (2). - С. 221-230.

9. A nationwide annual characterization of 25 years of forest disturbance and recovery for Canada using Landsat time series / J. C. White, M. A. Wulder, T. Hermosilla, N. C. Coops, G. W. Hobart // Remote Sensing of Environment. - 2017. - Vol. 194. - P. 303-321.

10. $\mathrm{Chu}, \mathrm{T}$. Remote sensing techniques in monitoring post-fire effects and patterns of forest recovery in boreal forest regions: A review / T. Chu, X. Guo // Remote Sensing. - 2014. - № 6. - P. 470-520.

11. Тюлина, Л. Н. Лиственничные леса северо-восточного побережья Байкала и западного склона Баргузинского хребта / Л. Н. Тюлина // Труды БИН им. В. Л. Комарова АН СССР. Сер.: Геоботаника. - 1954. Вып. 9. - С. 150-209.

12. LEDAPS Calibration, Reflectance, Atmospheric Correction Preprocessing Code, Version 2 / ed. by J. G. Masek, E. F. Vermote, N. Saleous, R. Wolfe, F. G. Hall, F. Huemmrich, F. Gao, J. Kutler, T. Lim. - ORNL DAAC, Oak Ridge, USA, 2013. - URL: https://daac.ornl.gov/MODELS/guides/ LEDAPS_V2.html (дата обращения: 31.10.2019).

13. Congedo, L. Semi-Automatic Classification Plugin Documentation / L. Congedo // QGIS Geographic Information System. Open Source Geospatial Foundation Project. - 2016. - URL: http://qgis.osgeo.org (дата обращения: 31.10.2019).

14. Барталев, С. А. Методология мониторинга и прогнозирования пирогенной гибели лесов на основе данных спутниковых наблюдений / С. А. Барталев, Ф. В. Стыценко, С. А. Хвостиков, Е. А. Лупян // Современные проблемы дистанционного зондирования Земли из космоса. - 2017. - № 14 (6). - С. 176-193.

15. FIREMON: Fire effects monitoring and inventory system / ed. by R. E. Keane, J. F. Caratti, C. H. Key, N. C. Benson, S. Sutherland, L. J. Gangi. - Rocky Mountain Research Station, Fort Collins, CO, USDA, Forest Service, 2006. -410 p.

16. Восстановление лесных экосистем после пожара / под ред. Л. П. Баранника. - Кемерово : КРЭОО ИРБИС, 2003. - $262 \mathrm{c}$.

17. Post-fire forest regeneration shows limited climate tracking and potential for drought-induced type conversion $/$ D. J. N. Young, C. M. Werner, K. R. Welch, T. P. Young, H. D. Safford, A. M. Latimer // Ecology. - 2019. № 100 (2). - P. e2571.

\section{References}

1. Lupyan E. A., Bartalev S. A., Balashov I. V., Egorov V. A., Ershov D. V., Kobets D. A., Sen'ko K. S., Stytsenko F. V., Sychugov I. G. Sovremennye problemy distantsionnogo zondirovaniya Zemli iz kosmosa [Modern problems of Earth's remote sensing from space]. 2017, no. 14 (6), pp. 158-175. [In Russian]

2. Tsvetkov P. A., Buryak L. V. Sibirskiy lesnoy zhurnal [Siberian forest journal]. 2014, № 3, pp. 25-42. [In Russian]

3. Conard S. G., Sukhinin A. I., Stocks B. J., Cahoon D. R., Davidenko E. P., Ivanova G. A. Climate Change. 2002 , no. 55, pp. 197-211.

4. Izuchenie estestvennogo khoda protsessov, protekayushchikh v prirode, $i$ vyyavlenie vzaimosvyazey mezhdu otdel'nymi chastyami prirodnogo kompleksa na territorii Barguzinskogo gosudarstvennogo prirodnogo biosfernogo zapovednika im. K. P. Zabelina. Letopis' prirody $2015 \mathrm{~g}$. [Styding the course of natural processes and identifying interconnections between separate parts of the natural complex in the territory of the Barguzinsky Nature Reserve. Nature records of 2015]. Eds. A. A. Ananin, T. L. Ananina. Ust-Barguzin: Zapovednoe Podlemor'e, 2016, 220 p. [In Russian]

5. Gamova N. S. Problemy botaniki Yuzhnoy Sibiri i Mongolii: sb. nauch. st. po materialam XIII Mezhdunar. nauch.prakt. konf. [Problems of South Siberian botany: collection of articles of XII International Research Conference]. Barnaul: Kontsept, 2014, pp. 55-59. [In Russian]

6. Krasnoshchekov Yu. N., Evdokimenko M. D., Onuchin A. A. Sibirskiy lesnoy zhurnal [Siberian forest journal]. 2018, no. 6, pp. 46-57. [In Russian]

7. Krasnoshchekov Yu. N., Evdokimenko M. D., Cherednikova Yu. S. Geografiya i prirodnye resursy [Geography and natural resources]. 2013, no. 1, pp. 33-42. [In Russian]

8. Krasnoshchekov Yu. N., Evdokimenko M. D., Cherednikova Yu. S., Boloneva M. V. Sibirskiy ekologicheskiy zhurnal [Siberian ecological journal]. 2010, no. 17 (2), pp. 221-230. [In Russian]

9. White J. C., Wulder M. A., Hermosilla T., Coops N. C., Hobart G. W. Remote Sensing of Environment. 2017, vol. 194, pp. 303-321.

10. Chu T., Guo X. Remote Sensing. 2014, no. 6, pp. 470-520. 
11. Tyulina L. N. Trudy BIN im. V. L. Komarova AN SSSR. Ser.: Geobotanika [Geobotany]. 1954, iss. 9, pp. 150-209. [In Russian]

12. LEDAPS Calibration, Reflectance, Atmospheric Correction Preprocessing Code, Version 2. Ed. by J. G. Masek, E. F. Vermote, N. Saleous, R. Wolfe, F. G. Hall, F. Huemmrich, F. Gao, J. Kutler, T. Lim. ORNL DAAC, Oak Ridge, USA, 2013. Available at: https://daac.ornl.gov/MODELS/guides/ LEDAPS_V2.html (accessed Oct. 31, 2019).

13. Congedo L. QGIS Geographic Information System. Open Source Geospatial Foundation Project. 2016. Available at: http://qgis.osgeo.org (accessed Oct. 31, 2019).

14. Bartalev S. A., Stytsenko F. V., Khvostikov S. A., Lupyan E. A. Sovremennye problemy distantsionnogo zondirovaniya Zemli iz kosmosa [Modern problems of Earth's remote sensing from space]. 2017, no. 14 (6), pp. $176-193$. [In Russian]

15. FIREMON: Fire effects monitoring and inventory system. Eds. by R. E. Keane, J. F. Caratti, C. H. Key, N. C. Benson, S. Sutherland, L. J. Gangi. Rocky Mountain Research Station, Fort Collins, CO, USDA, Forest Service, $2006,410 \mathrm{p}$.

16. Vosstanovlenie lesnykh ekosistem posle pozhara [Restoration of forest ecosystems after fires]. Ed. by L. P. Barannik. Kemerovo: KREOO IRBIS, 2003, 262 p. [In Russian]

17. Young D. J. N., Werner C. M., Welch K. R., Young T. P., Safford H. D., Latimer A. M. Ecology. 2019, no. 100 (2), p. e2571. 